\title{
rorum DIF AKADEMIKUS SE PLEK IN DIE SAW
}

\begin{abstract}
'Down the streets of Portsmouth, more than a hundred years ago, walked a sailor with one arm, one eye, a persistent state of nerves and unable to tread a ship's deck without being seasick. Indeed he would probably have been in a home for incurables, were not his name Admiral Lord Nelson. The man's spirit drove the flesh.'
\end{abstract}

So ' $n$ kandidaat soos hierbo beskrywe sou nie maklik 'n plek in die Suid-Afrikaanse Weermag gekry het nie. Die norm wat geld is of hy medies geskik is, of hy mooi lyk in uniform, of hy netjies salueer en nie of hy ' $n$ positiewe bydrae tot die slagvaardigheid van die land kan maak nie. Toegegee fiksheid en voorkoms is van groot belang vir die SuidAfrikaanse Weermag, maar wees realisties waar die verstandelike vermoë van groter belang is as die voorkoms.

Hierdie stelling hang saam met die doktrine dat Suid-Afrika in 'n oorlog betrokke is wat uit $20 \%$ skiet en $80 \%$ oorreding bestaan. Nou is dit so dat die Suid-Afrikaanse Weermag se opleidingsbeleid vir $100 \%$ gekonsentreerd is op die $20 \%$ stryd. Dus, ' $n$ logiese afleiding is dat die Suid-Afrikaanse Weermag vir die $80 \%$ stryd nie voorsiening maak by opleiding nie. Maar voordat hieruit afgelei word dat die Suid-Afrikaanse Weermag net $20 \%$ gereed is, moet daarop gewys word dat die mense, waarmee die $80 \%$ gedeelte 'geveg' moet word, van die straat af gewerf kan word.

Hierdie mense, wat die $80 \%$ moet lewer, word deur die Gevegsdienste, wat die $20 \%$ lewer, beskou as 'civvies in uniform'. Hulle word ook genoem die Korps van Professionele Offisiere.

Van hierdie groepie offisiere, wat 'n Staffunksie lewer, word ook verwag om hulle te bekwaam om 'n Lynfunksie te behartig. Met ander woorde hulle moet die suiwer Gevegsdienskursusse suksesvol voltooi anders is hufle nie waardig om deel van die Suid-Afrikaanse Weermag te wees nie. Hulle word nie aanvaar as deel van ' $n$ span nie ongeag die feit dat die Weermag hulle nodig het - anders kan die Weermag net $20 \%$ van sy taak volbring.

Die ideale toestand is natuurlik dat elke Weermagslid militêr sowel as akademies gekwalifiseerd moet wees. Maar hoe is dit moontlik om 'n outoriteit te wees in tale, etnologie, sosiologie, geografie, ensovoorts. So is dit ook onmoontlik om ' $n$ juris en ' $n$ narkotiseer te wees. Net so is dit ook onmoontlik om ' $n$ artilleris en ' $n$ vegvlieënier in een te wees.
Elke persoon het sy gebied waarop hy uitblink en waarvoor hy gekwalifiseerd is. Soms kan ' $n$ persoon twee of drie vakgebiede gelyktydig hanteer, maar dan sal hy nooit $100 \%$ sy beste kan lewer nie.

Om genoemde redes is dit dus noodsaaklik dat die infanteris toegelaat word om ' $n$ infanteris te bly en om hom die kans te gun om daardie gedeelte van sy taak binne die Suid-Afrikaanse Weermag 100\% te doen. Daarom ook moet die ekonoom toegelaat word om ekonoom te bly en moet hy ook die kans kry om sy gedeelte van sy taak binne die SuidAfrikaanse Weermag $100 \%$ te doen. Maar moet nooit van die infanteris ' $n$ halfgebakte ekonoom maak of van die ekonoom 'n halwe infanteris nie.

As daardie stadium in die Suid-Afrikaanse Weermag bereik word waar dit aanvaar word dat die blom en die by mekaar nodig het en dat die by nie slegs vir die blom daar is nie, dan sal die Korps van Professionele Offisiere ook tot sy reg kom. Dan eers sal die persoon wat akademies 'n outoriteit op sy gebied is aanvaar word as ' $n$ volwaardige lid van die Suid-Afrikaanse Weermag - al het hy 'n gebreklike voet.

Hierby moet in gedagte gehou word dat nou nog slegs die noodsaaklikheid van die Korps van Professionele Offisiere bewys is, maar die Suid-Afrikaanse Weermag het nog nie genoeg van hierdie mense om die $80 \%$,gedeelte te panteer nie. Die stelling is wel gemaak dat sodanide mense 'van die straat af gewerf kan word'. Maar is dit so maklik? Is die loopbaan wat geskets word kompeterend genoeg om die regte soort mense met die nodige kwalifikasies - te trek en te behou? Gedurende die Tweede Wêreldoorlog het die destydse Unieverdedigingsmag met ' $n$ skok besef dat hulle professionele offisiere op verskeie terreine nodig het. Met groot moeite is diesulkes toe gewerf, 'n rang gegee en - sonder kursusse - in die veld gestoot. $\mathrm{Na}$ die beëindiging van die oorlog is hulle gedemobiliseer.

Vandag is die Suid-Afrikaanse Weermag meer voorbereid. Die kern van die Korps van Professionele Offisiere bestaan reeds. Terwyl daar nou nog kans is, moet sake reggestel word. Die SuidAfrikaanse Weermag het baie professionele offisiere nodig. 